(C) Elsevier/Inra

Original article

\title{
Genetic parameters of feeding behaviour and performance traits in group-housed Large White and French Landrace growing pigs
}

\author{
F Labroue ${ }^{1,2 *}$, R Guéblez ${ }^{2}$, P Sellier ${ }^{1}$ \\ ${ }^{1}$ Département de génétique animale, Station de génétique quantitative et appliquée, \\ Institut national de la recherche agronomique, 78352 Jouy-en-Josas cedex; \\ 2 Institut technique du porc, La Motte au Vicomte, \\ BP 33, 35651 Le Rheu cedex, France
}

(Received 2 November 1996; accepted 14 August 1997)

\begin{abstract}
Summary - Data on feeding behaviour of 3710 group-housed and ad libitum fed growing pigs were recorded using 'Acema 48' electronic feed dispensers. Genetic parameters for six feeding behaviour criteria and the main production traits routinely recorded in French central test stations (three 'boar' traits and three 'sib' traits) were estimated in two breeds (Large White and French Landrace) using a multiple trait animal model DF-REML procedure. Heritability estimates for feeding behaviour criteria ranged from 0.36 to 0.54 and were markedly higher than that for the food conversion ratio (0.20). Heritability of daily feed intake was 0.42 in both breeds, whereas heritabilities of rate of feed intake, feed intake per meal and time per meal were slightly higher (0.45-0.54). Daily feed intake showed a very close genetic correlation (around 0.85 ) with average daily gain but also unfavourable genetic correlations with ultrasonic backfat thickness (around 0.5) and lean percentage (around -0.4). Daily feed intake was genetically independent of food conversion ratio, whereas average daily gain showed a favourable genetic correlation (around -0.35 ) with that trait. Among the feeding behaviour criteria, feed intake per meal and rate of feed intake showed the highest genetic correlations with daily feed intake (around 0.5) and average daily gain (around 0.4). They also showed moderately unfavourable genetic correlations with ultrasonic backfat thickness (around 0.25 ) and carcass lean percentage (around -0.25 ) and seemed to be genetically independent of food conversion ratio. The value of including a trait relating to feed intake pattern among traits selected for is discussed on the basis of this set of genetic parameters.
\end{abstract}

pig / genetic parameter / feeding behaviour / electronic feed dispenser / production trait

* Correspondence and reprints 
Résumé - Paramètres génétiques des critères de comportement alimentaire et des performances de production chez des porcs Large White et Landrace français élevés en groupe. Les données de comportement alimentaire de 3710 porcs en croissance élevés en groupes et alimentés à volonté ont été récoltées à l'aide de distributeurs automatiques d'aliment "Acema 48». Les paramètres génétiques de six critères de comportement alimentaire et des principaux caractères de production mesurés en routine dans les stations publiques de contrôle des performances (trois caractères «candidats» et trois caractères « collatéraux») ont été estimés dans deux races (Large White et Landrace français) à l'aide de la méthode du maximum de vraisemblance restreinte (REML) appliquée à un modèle animal multicaractère. Les héritabilités des critères de comportement alimentaire sont comprises entre 0,36 et 0,54, et sont nettement supérieures à celle de l'indice de consommation (0,20). L'héritabilité de la consommation moyenne journalière est de 0,42 dans chacune des deux races tandis que celles de la vitesse d'ingestion, de la consommation moyenne par repas ou de la durée des repas sont légèrement plus élevées (0,45-0,54). La consommation moyenne journalière présente une corrélation génétique très élevée (de l'ordre de 0,85) avec le gain moyen quotidien mais aussi des corrélations génétiques défavorables avec l'épaisseur de lard dorsal (de l'ordre de 0,5) et le pourcentage de muscle (de l'ordre de -0,4). La consommation moyenne journalière est génétiquement indépendante de l'indice de consommation tandis que le gain moyen quotidien présente une corrélation génétique favorable (de l'ordre de -0,35) avec ce caractère. Parmi les critères de comportement alimentaire, la consommation moyenne par repas et la vitesse d'ingestion sont les plus liées génétiquement à la consommation moyenne journalière (environ 0,5) et au gain moyen quotidien (environ 0,4). Ces critères présentent également des corrélations génétiques modérément défavorables avec l'épaisseur de lard dorsal (environ 0,25) et le pourcentage de muscle (environ-0,25) et semblent être génétiquement indépendants de l'indice de consommation. L'inclusion possible d'un critère de comportement alimentaire parmi les caractères sélectionnés est discutée sur la base de cet ensemble de paramètres génétiques.

porc / paramètre génétique / comportement alimentaire / distributeur automatique d'aliment / caractère de production

\section{INTRODUCTION}

The interest in studying appetite in growing pigs raised under ad libitum feeding conditions has grown since the early 1980s owing to the genetic trends that have occurred as a result of selection. Pig populations, which have become leaner and more efficient in terms of converting food to liveweight gain, generally exhibit lower daily feed intake (McPhee, 1981; Mitchell et al, 1982; Ellis et al, 1983; Brandt, 1987; Smith et al, 1991; Cameron and Curran, 1994). Such a decrease in daily feed intake under ad libitum feeding conditions could limit the long-term genetic improvement possible for daily lean tissue deposition. The inclusion of daily feed intake, or any other feeding behaviour criterion, among breeding goals requires the knowledge of genetic parameters for feeding behaviour criteria, including their genetic relationships with growth rate, feed efficiency and carcass lean to fat ratio.

The literature review made by Labroue (1995) concerning the appetite of growing pigs having ad libitum access to feed, showed a rather large variation in the genetic parameter estimates, especially for the genetic correlation between food conversion ratio and daily feed intake (range of available estimates: 0.01-1). In France, three central test stations have been equipped with 'Acema 48' electronic feed dispensers (Labroue et al, 1994b) since 1990, which has made it possible to collect enough 
data to study the genetic variability of feeding behaviour criteria. The aim of the present study was to estimate genetic parameters of the Large White and French Landrace breeds for feeding behaviour criteria and production traits using a restricted maximum likelihood (REML) procedure applied to a multi-trait animal model. The data used in the last complete estimation of genetic parameters for production traits measured in French central test stations (Ducos et al, 1993) were collected prior to the establishment of electronic feed dispensers. This estimation of genetic parameters therefore is the first one referring to the new central testing conditions prevailing in France.

\section{MATERIAL AND METHODS}

\section{Origin of data}

Data were collected on Large White (LW) and French Landrace (LR) pigs at three French central test stations (Argentré, Le Rheu, Mauron) between 1988 (beginning of ad libitum feeding in pens of around 12 pigs) and 1994. Since 1990, most pens in these stations have been equipped with an 'Acema 48' feed dispenser. Feed was distributed in pellets and contained $9.0 \mathrm{MJ} / \mathrm{kg}$ net energy and $170 \mathrm{~g} / \mathrm{kg}$ crude protein. During this period, testing was performed both on candidates for selection (entire males) and slaughtered sibs (castrated males). Breeders usually sent one triplet of pigs (two candidates and one full-sib) per litter. Animals were tested in successive batches ('all in-all out' system), each batch being defined as a group of contemporary animals entering the station within a 10-day period, having similar ages and liveweights (around 30 days and $7 \mathrm{~kg}$, respectively).

Young boars (candidates for selection) were tested between 35 and $95 \mathrm{~kg}$ liveweight. Beginning in 1990, feed intake was recorded individually throughout the test period (ie, the establishment of electronic feed dispensers). Backfat thickness was measured twice at the end of the test at liveweights around $95 \mathrm{~kg}$. The ultrasonic measurements were taken on each side of the spine, $4 \mathrm{~cm}$ from the middorsal line at the level of the shoulder, last rib and hip joint, respectively.

Castrated males (sibs) were tested between 35 and $100 \mathrm{~kg}$ liveweight. They were fed ad libitum during the whole test period, but individual feed intake was not recorded on all sibs in two stations. At these stations, the boars were preferentially raised in the pens equipped with an electronic feed dispenser. Sibs were slaughtered in a commercial abattoir at an average liveweight of $100 \mathrm{~kg}$. On the day after slaughter, a standardized cutting of one half-carcass was performed (Anonymous, 1990 ) and three meat quality measurements (ultimate $\mathrm{pH}$, reflectance and waterholding capacity) were taken on ham muscles as described by Tribout et al (1996).

Two data sets (one per breed) were created by considering all LW and LR boars and sibs tested from 1988 to 1994 in the three French central test stations (table I). Detailed information on individual feeding behaviour was available for all boars and a portion of the sibs tested between 1992 and 1994. For computational reasons, only two generations of ancestors, ie, the parents and grand-parents of tested animals, were considered. 


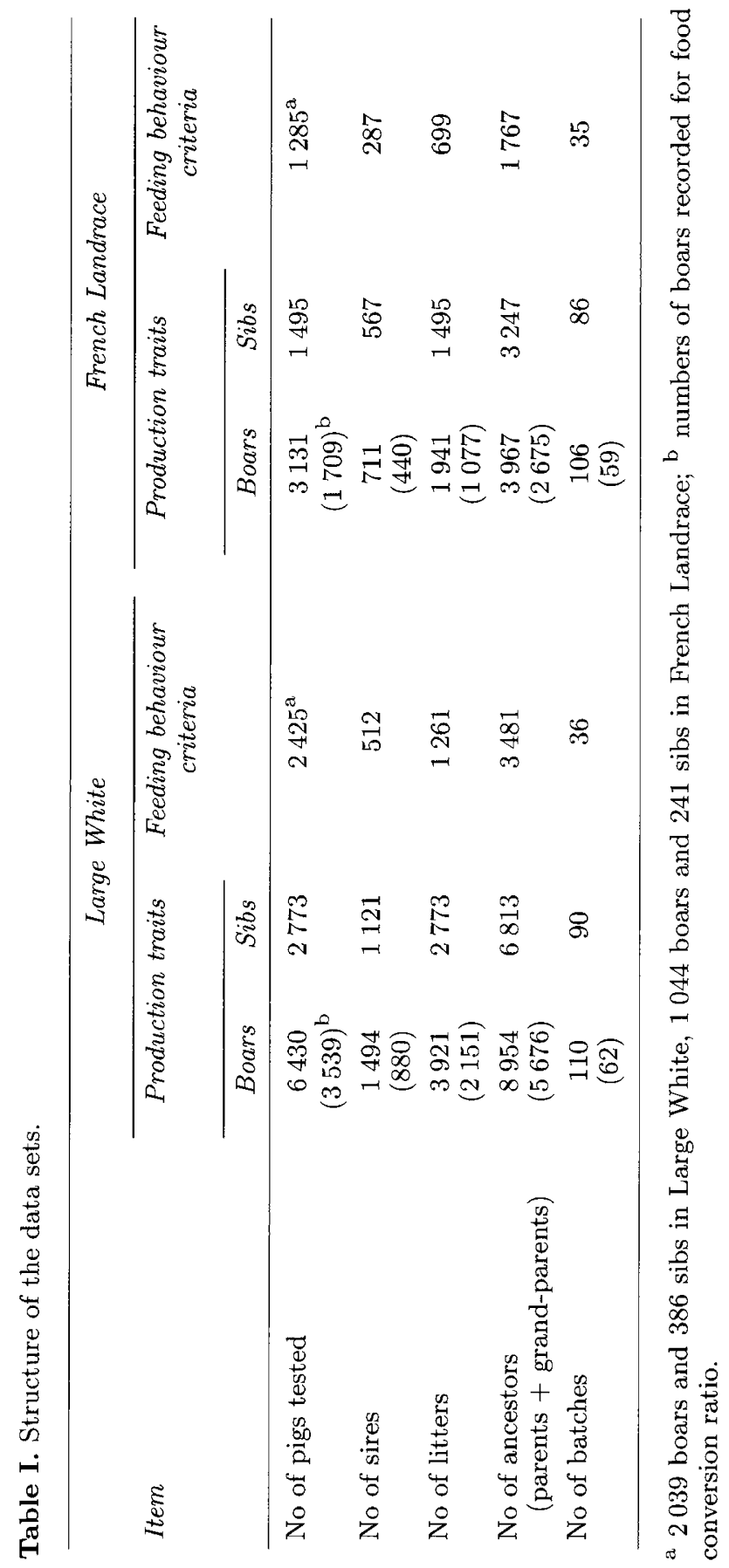




\section{Traits analyzed}

\section{Production traits}

Six performance traits were studied, namely:

three 'boar' traits: average daily gain, food conversion ratio and ultrasonic backfat thickness;

three 'sib' traits: dressing percentage computed as the ratio of carcass weight over slaughter liveweight, carcass lean content predicted from the proportions of six joints in the half-carcass (Anonymous, 1990; Bidanel and Ducos, 1996), and meat quality index established as a predictor of the technological yield of cured-cooked ham processing and consisting of a linear function of the three above-mentioned meat quality measurements (Guéblez et al, 1990; Tribout et al, 1996).

\section{Feeding behaviour criteria}

After each visit to the feed dispenser, animal number, time at the beginning and at the end of the visit and amount of feed consumed were recorded. Successive visits performed by the same animal within 2 min were grouped into the same meal as described by Labroue et al (1994b). The following six traits were defined for each pig:

three criteria relating to meal characteristics: average feed intake per meal $(\mathrm{g})$, average total time per meal ( $\mathrm{min}$ ) including eating time and time intervals between the visits, average number of meals per day;

three criteria relating to daily characteristics: average feed intake per day $(\mathrm{kg})$, average total eating time per day $(\mathrm{min})$ defined as the total duration of all visits made on the same day, average rate of feed intake $(\mathrm{g} / \mathrm{min})$ defined as the ratio of daily feed intake over daily eating time.

Feeding behaviour data were collected over a fixed period of 12 weeks for boars and 13 weeks for sibs, ie, the respective average times on test for entire and castrated males. The calculation of average feeding behaviour traits was performed using only 'full-record' days (Labroue, 1996).

Some pigs did not complete the test. The minimum duration of the test period was set to 10 weeks. Any pig dead or discarded before the 11 th week of test was removed from the analysis.

The number of pigs per pen ('group size') was based on the number of pigs that started the test. An animal present for less than 10 weeks was given a weight of 0.1 per week of presence. However, there were only very few accidental losses and group size usually remained unchanged throughout the test period. The average group size was 11 , with $85 \%$ of the pigs housed in pens of 9 to 13 animals. Boars and sibs were not raised together in the same pen, whereas LW and LR pigs were occasionally mixed together. An earlier study (Labroue et al, 1994b) had suggested that mixing pigs from these two breeds in the same pen could influence the feeding pattern of LR pigs. This was not confirmed in the present sample of pigs, and the effect of breed mixing or not was not included in the statistical model.

Elementary statistics for the 12 traits studied are given in table II. 


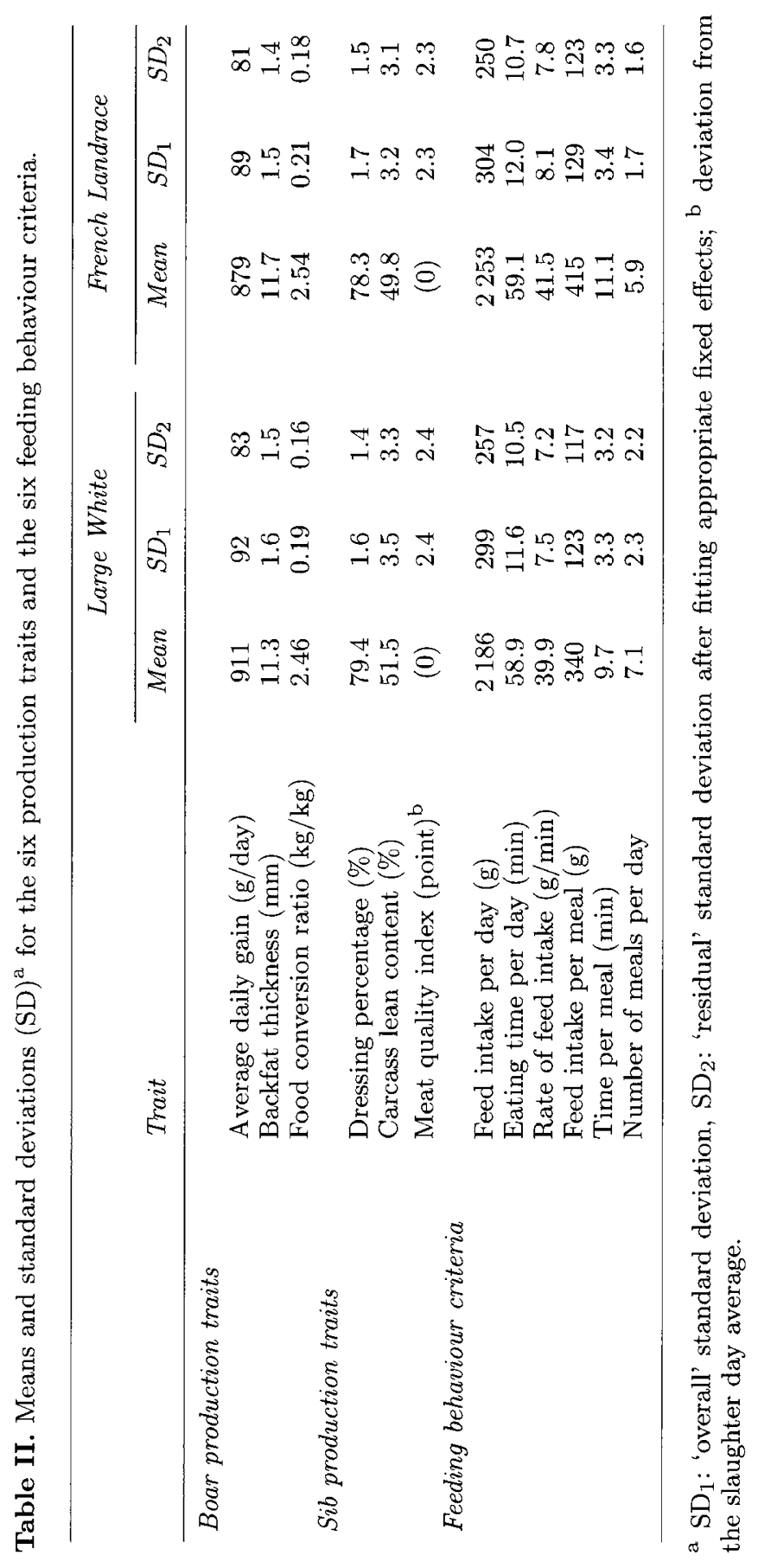




\section{Statistical model}

The model varied depending on the trait, but had the following basic form in matrix notation:

$$
\mathbf{y}=\mathbf{X b}+\mathbf{W} \mathbf{p}+\mathbf{Z a}+\mathbf{e}
$$

where $\mathbf{y}$ is the vector of observations, $\mathbf{b}$ is the vector of fixed effects, $\mathbf{p}$ is the vector of random litter effects, $\mathbf{a}$ is the vector of random additive genetic values of animals, $\mathbf{e}$ is the vector of residuals, and $\mathbf{X}, \mathbf{W}, \mathbf{Z}$ are incidence matrices relating observations to the effects included in the model.

The statistical model used for each trait or group of traits is shown in table III. For feeding behaviour traits, the model used was chosen following the results of two earlier studies on factors influencing feeding behaviour in group-housed growing pigs (Labroue et al, 1994a, b). The three fixed effects taken into account were: sex (entire or castrated males), batch (35 or 36 levels, depending on the breed) and group size $(\leqslant 7,8,9,10,11,12,13, \geqslant 14)$. Preliminary analyses showed that the first-order interactions among fixed effects were not significant for any trait, and no interaction term was included in the model. The random litter effect was not taken into account in the model applied to the three ' $\mathrm{sib}$ ' traits. Indeed, there was only one castrated male in $98.7 \%$ of LW and $99.1 \%$ of LR litters, precluding the possibility of obtaining a reliable estimation of litter effects for 'sib' traits. A random sampling of one castrated male was therefore performed in the very few litters containing two castrated males.

\section{Computing strategies}

Variance and covariance components were estimated by the multivariate REML using the derivative-free algorithm described by Groeneveld (1991). It was not computationally possible to analyze all the traits at once. For the traits sharing the same model of analysis, only 4- or 5-trait analyses reached convergence within an acceptable computing time. As a result, several analyses using different combinations of traits were performed for each breed. Moreover, for estimating the (co)variance components for traits submitted to different models of analysis, only 2-trait analyses (including one production trait and one feeding behaviour trait) could be performed for each breed. In all cases, a Quasi-Newton (DF-QN) algorithm (UNCMIN option of VCE 3.2 software package) was used to maximize the likelihood function because of its good convergence rate (Groeneveld, 1993). The convergence criterion $(\mathrm{CC})$ was defined as $\mathrm{CC}=\max \left[\phi^{(\mathrm{t})}-\phi^{(\mathrm{t}-1)}\right]$, where $\phi^{(t)}$ and $\phi^{(t-1)}$ are the vectors of parameters estimated at iteration $t$ and $t-1$, respectively. The stopping criterion was set at $5 \cdot 10^{-3}$. The total number of iterations ranged from 35 to 42 for the 2-trait analyses and from 58 to 120 for the 4- or 5-trait analyses.

Lower bounds of standard errors of genetic parameters were obtained from the approximate Hessian matrix when convergence was reached. 


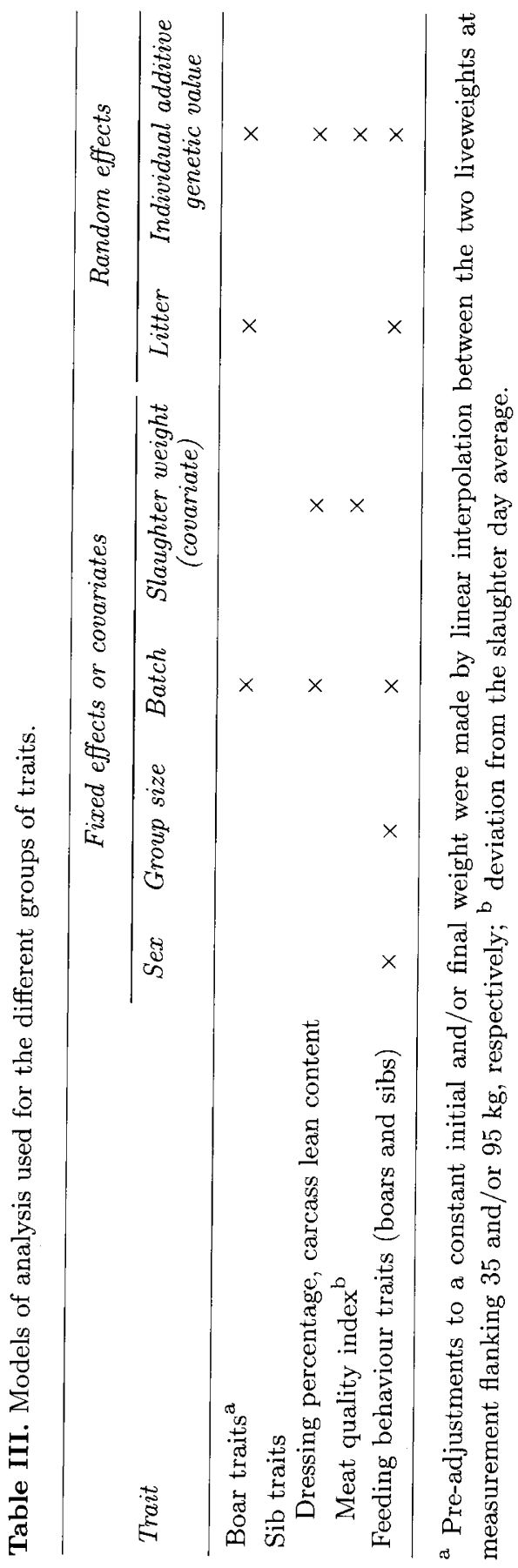




\section{RESULTS}

\section{Production traits}

As shown in table IV, traits pertaining to carcass lean to fat ratio showed the highest heritabilities $\left(h^{2}\right.$ ranging from 0.60 to 0.76 ). Heritability estimates for average daily gain were about 0.35 . Heritability values were similar in both breeds (around 0.20 ) for food conversion ratio and meat quality index, but were larger in the LW than in the LR breed for dressing percentage. Common environmental effects $\left(c^{2}\right)$ were small for live backfat thickness but were larger for average daily gain and food conversion ratio.

The two traits predicting carcass lean to fat ratio, ie, live backfat thickness in boars and carcass lean content in sibs, showed high genetic correlations $(-0.84$ and -0.79 in LW and LR breeds, respectively). Average daily gain and food conversion ratio were negatively (ie, favourably) correlated, with a more pronounced genetic association in the LR than in the $L W$ breed $(-0.47$ versus -0.24$)$. Genetic relationships between average daily gain and carcass lean to fat ratio were moderate in both breeds $\left(r_{\mathrm{A}}\right.$ of about -0.20$)$. Genetic correlations between meat quality index and average daily gain were low in both breeds and the genetic correlation between meat quality index and food conversion ratio were unfavourable. A noticeable genetic antagonism was also found between meat quality index and carcass lean to fat ratio $\left(r_{\mathrm{A}}\right.$ of about -0.35$)$ whatever the breed.

\section{Feeding behaviour criteria}

Most heritability estimates of feeding behaviour criteria were in the range $0.42-$ 0.50 (table V). Whatever the breed, the highest heritabilities were found for rate of feed intake (about 0.50) and the three criteria relating to meal characteristics $(0.42-0.54)$. The heritability value of feed intake per day was 0.42 in both breeds. Common environmental effects were higher in the LR (7-11\% of the phenotypic variance) than in the $\mathrm{LW}$ breed $(2-6 \%)$.

Genetic correlations among feeding behaviour criteria were similar in both breeds. Phenotypic correlations in absolute value were most often lower than genetic correlations. In both breeds, high genetic correlations, larger than 0.79 in absolute value, were found between daily number, size and duration of meals. Thus, pigs eating larger meals consumed a few long meals per day, and there seemed to be a range of feeding patterns varying from 'large meal eaters' (a few long meals per day) to 'nibblers' (many short meals per day). Feed intake per day showed positive genetic correlations $(0.40-0.60)$ with feed intake per meal and rate of feed intake. These fairly high genetic correlations as well as the negative genetic correlation (around -0.33 ) found between feed intake per day and number of meals per day indicate that breeding for increased appetite would lead to 1) 'large meal eaters' rather than 'nibblers' and 2) pigs having a higher rate of feed intake. In contrast, daily eating time would not be greatly affected.

\section{Genetic correlations between production traits and feeding behaviour criteria}

Among the studied feeding behaviour criteria, feed intake per day was the most closely correlated with production traits (table VI). The highest genetic correlations 


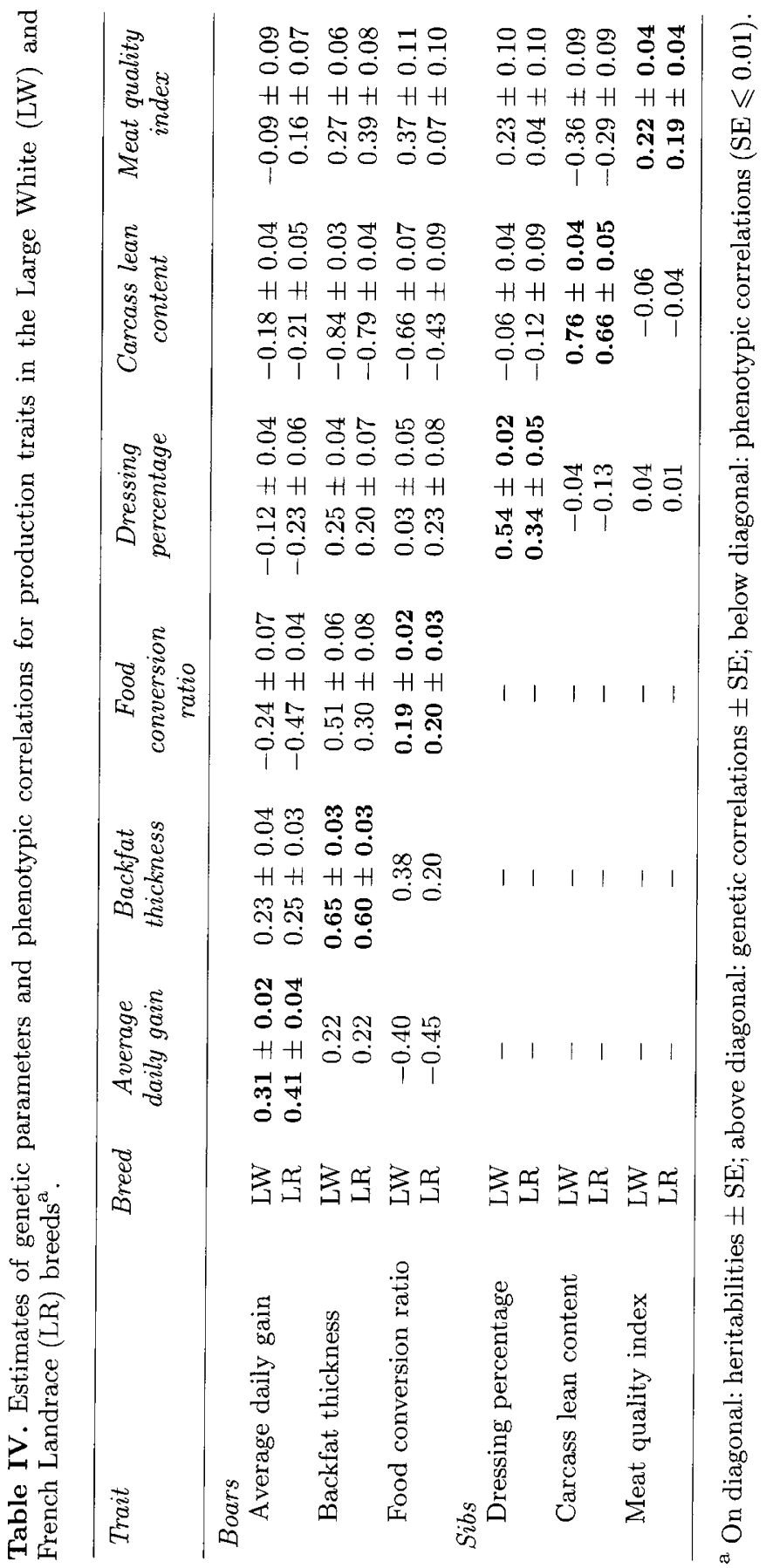




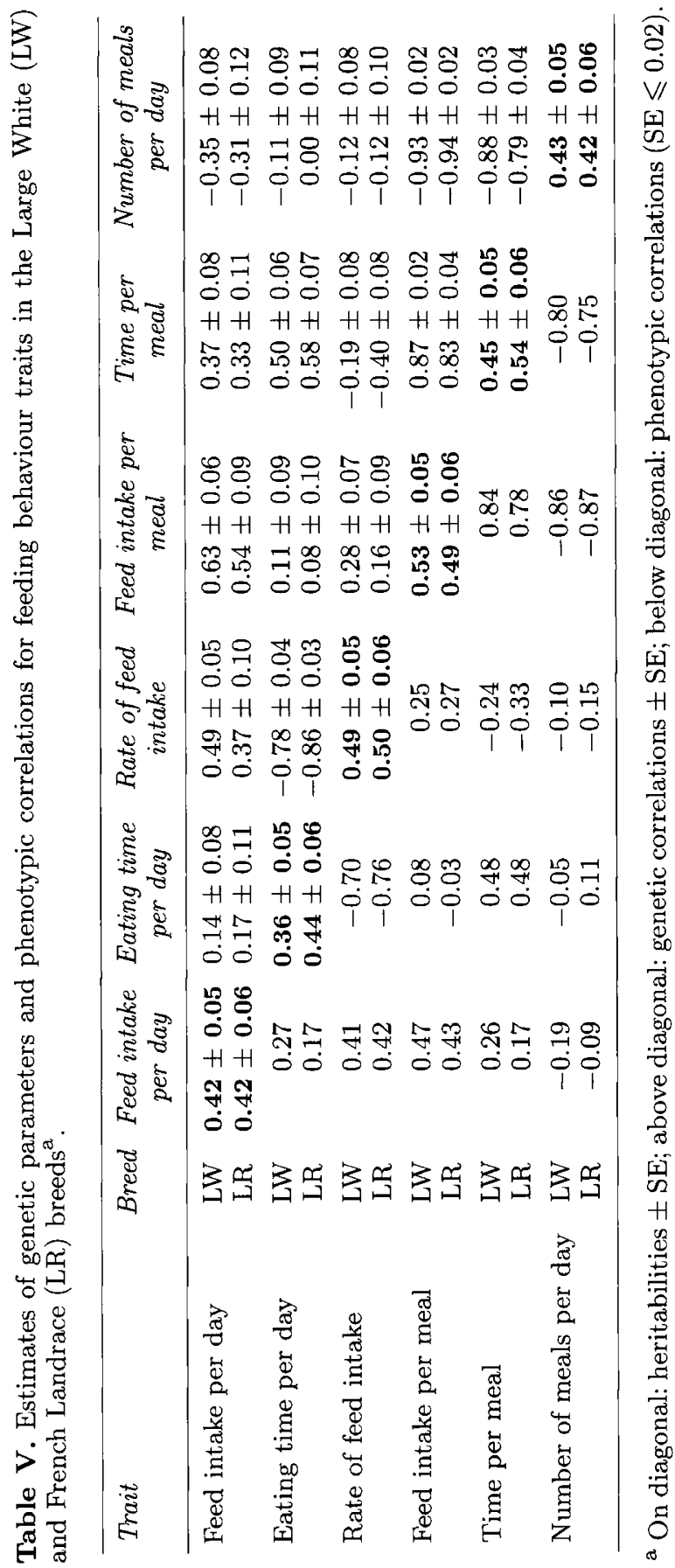


(around 0.85) were found between feed intake per day and average daily gain. Whatever the breed, the genetic correlation between daily feed intake and food conversion ratio was close to zero. However, the genetic antagonism between daily feed intake and carcass lean content was noticeably stronger in the LR than in the LW breed. Genetic correlations of feed intake per day with dressing percentage or meat quality index were rather low in both breeds.

Among behavioural criteria other than feed intake per day, feed intake per meal and rate of feed intake showed the closest genetic associations with production traits. They were positively correlated with average daily gain (about 0.50 and 0.30 in LW and LR, respectively) but negatively correlated with carcass lean content (about -0.30 and -0.20 in LW and LR, respectively). Genetic correlations of rate of feed intake or feed intake per meal with production traits were of the same sign as those found between feed intake per day and production traits, while being lower in absolute value. Other feeding behaviour criteria (eating time per day, number and duration of meals) showed fairly low genetic correlations with production traits. However, in LR, food conversion ratio was genetically correlated with duration of meals and rate of feed intake, whereas carcass lean content was genetically correlated with number of meals per day.

\section{DISCUSSION}

\section{Methodological aspects}

There is a general agreement that REML methodology applied to an individual animal model (IAM) is the method of choice for estimating location and dispersion parameters for traits described by linear models, because of its desirable statistical and genetic properties. In particular, this method accounts for the effects of selection if all the information related to selection is included in the analysis (Sorensen and Kennedy, 1984; Gianola et al, 1989). Nevertheless, the use of multivariate REMLIAM for a single analysis of large data sets requires substantial computational facilities, and generally researchers use limited applications, which can be performed with some deviations from the optimal situation.

The present data set had several drawbacks, such as different traits being measured on different individuals, low numbers of offspring recorded per sire and per litter, and a very low proportion of performance-tested parents. As a result, there were convergence problems, which were solved by 1) limiting the number of generations of ancestors taken into account in the pedigree file, 2) setting the litter covariance components to zero when analyzing traits described by different statistical models, and 3) running analyses that included at most two to five traits. Limiting the number of ancestors and the number of covariance components resulted in a reduction of the number of likelihood functions to be computed and of the CPU time per likelihood. The impact of 1) was investigated in LR. Adding a third generation of ancestors increased computing time considerably, but did not change the estimates of variance components at all (Labroue, 1996). The impact of 3 ) is theoretically more critical. All selected traits should be included in the analysis to properly take into account the effects of selection. The consequences of this simplification could not be accurately assessed. The satisfactory stability of the 


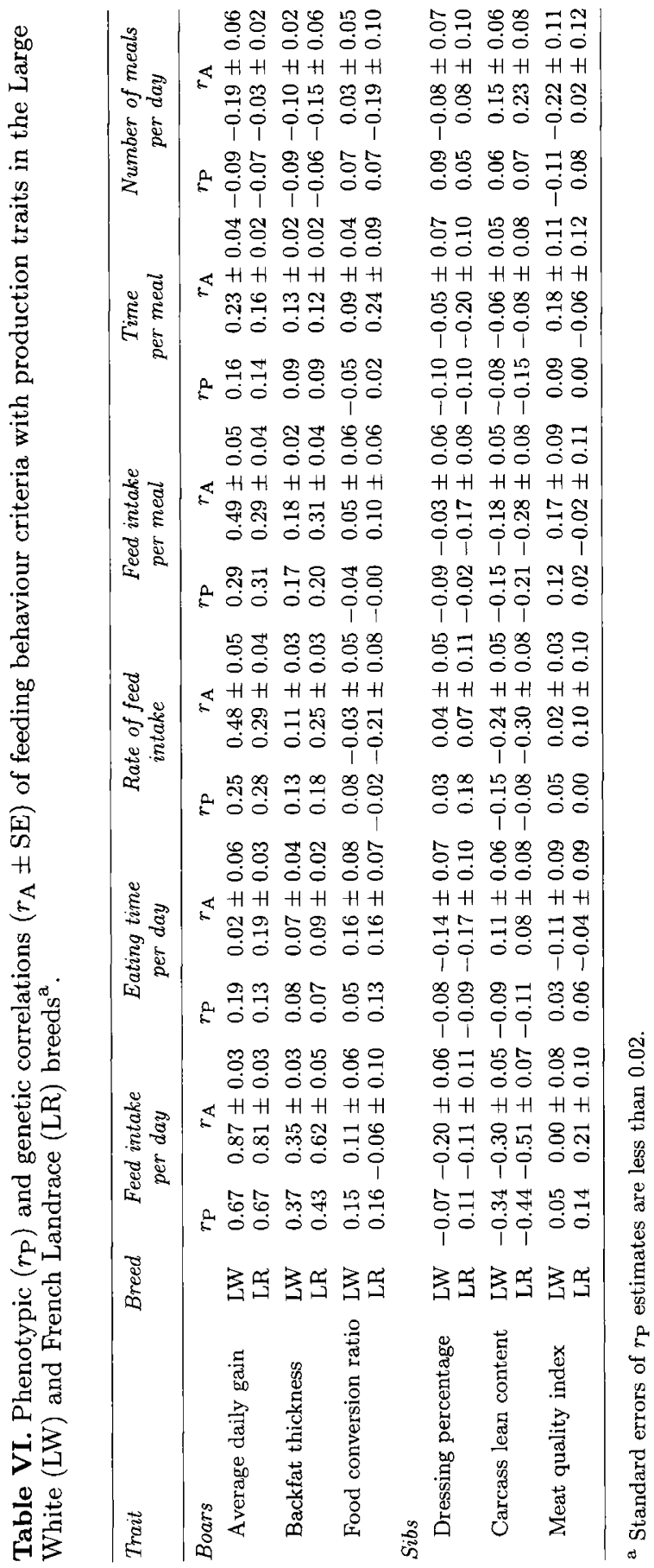


estimates of variance components obtained for a given trait from different analyses (within or between groups of traits) tends to indicate that these consequences should be rather limited, at least for variances. However, positive definiteness of the reconstructed variance-covariance matrices is no longer guaranteed. The consistency of variance-covariance matrices was tested in both breeds for each group of traits, and positive definiteness was obtained for all these matrices (Labroue, 1996). Another drawback of the present data set was the imbalance between numbers of boars and sibs measured for feeding behaviour criteria. Owing to the low numbers of sibs recorded for feeding behaviour, it was thought that studying 'boar' and 'sib' feeding behaviour criteria separately would not provide reliable estimates of genetic parameters for sibs.

\section{Heritabilities}

Heritability estimates for production traits are generally in agreement with those found in recent studies dealing with the traits routinely recorded in French central test stations (Ducos et al, 1993; Bidanel and Ducos, 1996). In comparison with earlier French studies (Ollivier et al, 1981; Tibau i Font and Ollivier, 1984) and with the literature review of Ducos (1994), the most pronounced differences in heritability estimates concern the relatively low values obtained for food conversion ratio as well as the relatively high values obtained for ultrasonic backfat thickness. These differences probably originate from the differences in feeding conditions (ad libitum versus restricted or 'to appetite' feeding) knowing that the variation in genetic parameter estimates due to feeding regime is well established in pigs (Cameron et al, 1988). For heritability of food conversion ratio, our estimates (around 0.20) are the same as that found by Von Felde et al (1996) for similar breeds and testing environment.

The present heritability estimate for feed intake per day ( 0.42 in both breeds) is slightly greater than the average literature value of 0.32 reported by Labroue (1995). For the other feeding behaviour criteria, the present results can be compared with those obtained in recent studies carried out under group-housing conditions using electronic feed dispensers, either 'IVOG' stations (De Haer and De Vries, 1993) or 'Acema 48' feeders (Von Felde et al, 1996). In the study of De Haer and De Vries (1993), heritability estimates for feeding behaviour criteria ranged from 0.24 to 0.49 , but with fairly large standard errors $(0.16-0.24)$ due to the limited size of the data set. Feeding duration was the least heritable criteria $\left(h^{2}=0.25\right.$ on average), whereas the daily number of meals was more heritable $\left(h^{2}=0.45\right)$. Feed intake per meal had a rather high heritability (0.47), whereas feed intake per day had a markedly lower heritability (0.16) than in the present study. According to Von Felde et al (1996), heritability of feed intake per day between the liveweights of 48 and $117 \mathrm{~kg}$ showed some variation over time and reached its maximum value $\left(h^{2}=0.30\right.$ ) in the middle of the test period. Over the whole testing period, the heritability estimates reported by these authors are $0.22 \pm 0.06$ for feed intake per day and $0.42-0.51$ for other feeding behaviour criteria. All available results agree that the feeding behaviour criteria of group-housed growing pigs, as assessed by use of electronic feed dispensers, are moderately to highly heritable. 


\section{Genetic correlations}

For 'boar' and 'sib' production traits, the set of genetic correlations estimated in the present study shares several common features with that from the most recently published study carried out in France on the same traits and breeds (Ducos et al, 1993). Both studies show very close genetic relationships between similar traits measured on animals of different sex types $\left(r_{\mathrm{A}}\right.$ of -0.8 to -0.9 between live backfat thickness of boars and carcass lean percentage of sibs) as well as moderately unfavourable genetic correlations of average daily gain with ultrasonic backfat thickness of boars (around 0.3) or carcass lean percentage of sibs (around -0.2). However, a noticeable difference between the two studies concerns the relationships between average daily gain, food conversion ratio and live backfat thickness. The study of Ducos et al (1993) dealt with data collected in 1980-1990, and most of the boars involved had been fed 'to appetite' (two meals per day). In that study, food conversion ratio was much more closely associated at both phenotypic and genetic levels with average daily gain $\left(r_{\mathrm{P}}\right.$ and $r_{\mathrm{A}}$ of about -0.7 and -0.6 , respectively) than with ultrasonic backfat thickness $\left(r_{\mathrm{P}}\right.$ and $r_{\mathrm{A}}$ of about 0.1 and 0.3 , respectively). Conversely, all boars involved in the present study were fed ad libitum, and food conversion ratio appeared to be associated to the same extent with average daily gain and backfat thickness. When averaged over LW and LR breeds, the phenotypic as well as genetic correlations turned out to be around -0.40 for average daily gain and 0.35 for backfat thickness.

To our knowledge, estimates of genetic correlations among feeding behaviour criteria have, so far, been reported only by Von Felde et al (1996). However, De Haer and Merks (1992), Labroue et al (1994b), Young and Lawrence (1994) and Hyun et al (1997) reported phenotypic correlations between these criteria. The main differences between the study of Von Felde et al (1996) and the present one concern the genetic relationships between feed intake per day, eating time per day and rate of feed intake. As previously reported by De Haer and Merks (1992) and Young and Lawrence (1994) at the phenotypic level, Von Felde et al (1996) reported a fairly low genetic correlation $\left(r_{\mathrm{A}}=0.31\right)$ between daily feed intake and rate of feed intake but higher genetic correlations of daily eating time with daily feed intake $\left(r_{\mathrm{A}}=0.44\right)$ and rate of feed intake $\left(r_{\mathrm{A}}=-0.62\right)$. In the present study, rate of feed intake was closely correlated with daily eating time $\left(r_{\mathrm{P}}=-0.73\right.$ and $r_{\mathrm{A}}=-0.82$ when averaged over the two breeds), and, to a lesser extent, with daily feed intake $\left(r_{\mathrm{P}}=0.41\right.$ and $\left.r_{\mathrm{A}}=0.43\right)$, but daily feed intake and daily eating time were poorly correlated $\left(r_{\mathrm{P}}=0.22\right.$ and $\left.r_{\mathrm{A}}=0.15\right)$. In contrast, there is good agreement between the two studies regarding the very close genetic correlations (about 0.8 in absolute value) between size, duration and daily number of meals.

Concerning the genetic relationships between daily feed intake and production traits, the genetic correlation estimated in the present study between feed intake per day and average daily gain ( 0.84 on average over the two breeds) is slightly higher than the average literature value of 0.71 reported by Labroue (1995) and the value of 0.68 found by Von Felde et al (1996). The genetic correlation between feed intake per day and ultrasonic backfat thickness ( 0.48 on average) is very close to the value of 0.45 reported by Labroue (1995) and Von Felde et al (1996). This genetic antagonism between daily feed intake and carcass lean to fat ratio might be unfavourable to the efficiency of their joint selection. In contrast, there seems to be 
a genetic independence between feed intake per day and food conversion ratio $\left(r_{\mathrm{A}}\right.$ of 0.11 or -0.06 depending on the breed), which agrees with the corresponding value of $0.13 \pm 0.28$ reported by Von Felde et al (1996) but not with the average literature value of 0.37 quoted by Labroue (1995). However, the latter author pointed out that this pair of traits shows an extremely broad range of variation $(0.01-1.00)$ for the available estimates of genetic correlation between the two traits under ad libitum feeding conditions.

Feeding behaviour criteria other than feed intake per day are also somewhat associated with production traits. According to De Haer et al (1993) and Hyun et al (1997), feed intake per meal and rate of feed intake are the most closely correlated with production traits at the phenotypic level, the highest correlations (around 0.4) occurring for average daily gain. The same general pattern was found here at the genetic level, but relationships were slightly less close. In our study, the highest genetic correlations for average daily gain were found with rate of feed intake and feed intake per meal (around 0.4 when averaged over LW and LR breeds). The corresponding estimates reported by Von Felde et al (1996) tended to be lower (around 0.25). In the present study, feed intake per meal and rate of feed intake also showed moderately unfavourable genetic correlations with ultrasonic backfat thickness (around 0.25) and carcass lean percentage (approximately -0.25). Considering this moderate genetic antagonism with carcass lean to fat ratio, these two criteria could form an interesting alternative for selection. Von Felde et al (1996) also reported a positive genetic correlation of 0.32 between average daily gain and daily eating time, whereas the corresponding estimate was only 0.11 , when averaged over the two breeds, in the present study. As a general rule, food conversion ratio and carcass lean to fat ratio showed low genetic correlations with feeding behaviour criteria apart from daily feed intake in the present study as well as in the study of Von Felde et al (1996). A feature common to the two studies appears to be the moderate genetic correlation (around -0.2 ) of carcass lean to fat ratio with rate of feed intake.

\section{CONCLUSION}

Reliable estimates of genetic parameters make it possible to consider ways of enhancing genetic improvement of growing pigs while preventing a decrease in daily feed intake. The direct inclusion of the latter trait in the overall breeding objective would underline two problems: 1) the choice of an economic weight and 2) the genetic antagonism between daily feed intake and carcass lean to fat ratio, which may adversely affect the efficiency of their joint selection. As more unfavourable genetic correlations of carcass lean to fat ratio are found with daily feed intake than with feed intake per meal or rate of feed intake, the two latter traits could form an interesting alternative for selection. However, the expected genetic response for daily feed intake would be lower because the genetic correlations of those traits with daily feed intake itself are only 0.4 . It might be worth investigating whether taking into account certain feeding behaviour criteria could improve the overall efficiency of selection or not. The present study highlights that heritabilities of feed intake per day, rate of feed intake or feed intake per meal are twice as large as that of food conversion ratio $(0.4-0.5$ versus 0.2$)$. Also, that feed efficiency is fairly well 
predicted at the genetic level by the combination of average daily gain and carcass lean to fat ratio under ad libitum feeding conditions. It is suggested that it might be valuable to replace food conversion ratio by a trait relating to feed intake pattern in the selection indexes used in pig breeding programmes.

\section{ACKNOWLEDGMENTS}

We gratefully acknowledge M Bouffaud, D Brault, D Breton, E Cherel, C Perrocheau and the staff of French central test stations for their valuable help. Thanks are due to D Boichard for having developed methods of computing sampling variances of genetic parameters estimated by the VCE package as well as to the anonymous reviewers for their pertinent comments. This work was supported by a doctoral thesis scholarship given to the first author by INRA and ITP and by grants from INRA (AIP 'Déterminisme génétique de l'appétit') and the French Ministry of Agriculture.

\section{REFERENCES}

Anonymous (1990) Résultats du 16e test d'évaluation des performances de croissance, de composition corporelle et de qualité de la viande des produits terminaux des schémas de sélection et croisement. Techni-Porc 13(5), 29-45

Bidanel JP, Ducos A (1996) Genetic correlations between test station and on-farm performance traits in Large White and French Landrace pig breeds. Livest Prod Sci 45, $55-62$

Brandt H (1987) Development and genetic aspects of feed intake in three breeds of pigs at German test stations and measures to prevent further deterioration. Pig News Info $8,29-33$

Cameron ND, Curran MK (1994) Selection for components of efficient lean growth rate in pigs: 4. Genetic and phenotypic parameter estimates and correlated responses in performance test traits with ad-libitum feeding. Anim Prod 59, 281-291

Cameron ND, Curran MK, Thompson R (1988) Estimation of sire with feeding regime interaction in pigs. Anim Prod 46, 87-95

De Haer LCM, De Vries AG (1993) Effects of genotype and sex on the feed intake pattern of group housed growing pigs. Livest Prod Sci 36, 223-232

De Haer LCM, Merks JWM (1992) Patterns of daily food intake in growing pigs. Anim Prod 54, 95-104

De Haer LCM, Luiting P, Aarts HLM (1993) Relations among individual (residual) feed intake, growth performance and feed intake pattern of growing pigs in group housing. Livest Prod Sci 36, 233-253

Ducos A (1994) Paramètres génétiques des caractères de production chez le porc: mise au point bibliographique. Techni-Porc 17(3), 35-67

Ducos A, Bidanel JP, Ducrocq V, Boichard D, Groeneveld E (1993) Multivariate restricted maximum likelihood estimation of genetic parameters for growth, carcass and meat quality traits in French Large White and French Landrace pigs. Genet Sel Evol 25, 475-493

Ellis M, Smith WC, Henderson R, Whittemore CT, Laird R (1983) Comparative performance and body composition of control and selection line in Large White pigs. 2 . Feeding to appetite for a fixed time. Anim Prod 36, 407-413

Gianola D, Fernando RL, Im S, Foulley JL (1989) Likelihood estimation of quantitative genetic parameters when selection occurs: models and problems. Genome 31, 768-777 
Groeneveld E (1991) Simultaneous REML estimation of 60 covariance components in an animal model with missing values using the Downhill Simplex algorithm. 42nd Annual Meeting of the European Association for Animal Production, 8-12 September 1991, Berlin

Groeneveld E (1993) REML VCE - a multivariate multimodel restricted maximum likelihood (co)variance component estimation package. In: Proc EC Seminar on Application of Mixed Linear Models in the Prediction of Genetic Merit in Pigs (E Groeneveld, ed), 27 May 1993, Mariensee, 83-102

Guéblez R, Le Maître C, Jacquet B, Zert P (1990) Nouvelles équations de prédiction du rendement technologique de la fabrication du jambon de Paris. In: 22 ${ }^{e}$ Journées de la recherche porcine en France, Paris, 30-31 janvier et 1er février 1990, Institut technique du porc, Paris, 89-96

Hyun Y, Ellis M, McKeith FK, Wilson ER (1997) Feed intake pattern of group-housed growing-finishing pigs monitored using a computerized feed intake recording system. $J$ Anim Sci 75, 1443-1451

Labroue F (1995) Facteurs de variation génétiques de la prise alimentaire chez le porc en croissance: le point des connaissances. Inra Prod Anim 8, 239-250

Labroue F (1996) Aspects génétiques du comportement alimentaire chez le porc en croissance. Thèse de Doctorat, Ensar, Rennes

Labroue F, Guéblez R, Meunier-Salaün MC, Sellier P (1994a) Effets des facteurs liés au groupe sur le comportement alimentaire des porcs en croissance. In: $26^{e}$ Journées de la recherche porcine en France, Paris, 1-3 février 1994, Institut technique du porc, Paris, 299-304

Labroue F, Guéblez R, Sellier P, Meunier-Salaün MC (1994b) Feeding behaviour of grouphoused Large White and Landrace pigs in French central test stations. Livest Prod Sci 40, 303-312

McPhee CP (1981) Selection for efficient lean growth in a pig herd. Austr J Agric Res 32, $681-690$

Mitchell G, Smith C, Makower M, Bird PJWN (1982) An economic appraisal of pig improvement in Great Britain. 1. Genetic and production aspects. Anim Prod 35, 215224

Ollivier L, Derrien A, Molénat M (1981) Paramètres génétiques des femelles Large White et Landrace Français du contrôle de descendance sur la période 1970-1978. In: $13^{e}$ Journées de la recherche porcine en France, Paris, 4-5 février 1981, Institut technique du porc, Paris, 293-297

Smith WC, Ellis M, Chadwick JP, Laird R (1991) The influence of index selection for improved growth and carcass characteristics on appetite in a population of Large White pigs. Anim Prod 52, 193-199

Sorensen DA, Kennedy BW (1984) Estimation of response to selection using least squares and mixed model methodology. J Anim Sci 58, 1097-1106

Tibau i Font J, Ollivier L (1984) La sélection en station chez le porc (Bull Tech Dép Génét Anim $n^{\circ} 37$ ), Inra Publications, Versailles

Tribout T, Garreau H, Bidanel JP (1996) Paramètres génétiques de quelques caractères de qualité de la viande dans les races porcines Large White et Landrace Français. In: $28^{e}$ Journées de la recherche porcine en France, Paris, 30-31 janvier et $1^{\text {er }}$ février 1996, Institut technique du porc, Paris, 31-38

Von Felde A, Roehe R, Looft H, Kalm E (1996) Genetic association between feed intake behaviour at different stages of growth of group-housed boars. Livest Prod Sci 47, 11-22

Young RJ, Lawrence AB (1994) Feeding behaviour of pigs in groups monitored by a computerized feeding system. Anim Prod 58, 145-152 